\title{
Battery charging and discharging control of a hybrid energy system using microcontroller
}

\author{
Triyanto Pangaribowo ${ }^{1}$, Wahyu Mulyo Utomo ${ }^{2}$, Afarulrazi Abu Bakar ${ }^{3}$, Deni Shidqi Khaerudini ${ }^{4}$ \\ ${ }^{1}$ Department of Electrical Engineering, Faculty of Engineering, Universitas Mercu Buana, Indonesia \\ ${ }^{2,3}$ Faculty of Electrical and Electronic Engineering, Universiti Tun Hussein Onn Malaysia, Malaysia \\ ${ }^{4}$ Indonesian Institute of Sciences, Puspitek Serpong, Indonesia
}

\begin{tabular}{l} 
Article Info \\
\hline Article history: \\
Received Jun 6, 2019 \\
Revised Aug 8, 2019 \\
Accepted Aug 22, 2019 \\
\hline Keywords: \\
Battery \\
Charging and discharging \\
Control system \\
Hybrid energy system
\end{tabular}

\begin{abstract}
This study aims to control charging and discharging the battery for hybrid energy systems. The control system works by selecting the right energy source to supply voltage to the load. And also this control system can regulate charging and discharging the battery automatically. The voltage source consists of two energy, namely from the battery and DC source. The control system that has been designed has the ability to choose the right DC source when the battery capacity is less than $80 \%$. This system also has a good ability to choose a battery source when the battery reaches $100 \%$ capacity and the DC source has a voltage drop of more than $20 \%$. This control system is equipped with excessive electric current protection so that the security level is high.
\end{abstract}

Copyright $(2020$ Institute of Advanced Engineering and Science. All rights reserved.

\section{Corresponding Author:}

Triyanto Pangaribowo, Department Of Electrical Engineering, Universitas Mercu Buana, Jl. Meruya Selatan, No 1 Kembangan, Jakarta Barat, Indonesia.

Email: triyanto.pangaribowo@mercubuana.ac.id

\section{INTRODUCTION}

Renewable energy such as solar radiation as an energy source to reduce the energy crisis. Energy from photovoltaic panels can be used to charge the battery. The battery charge control regulates the flow of electricity from the photovoltaic panel to the battery or DC load [1]. Battery energy storage systems (BESS) is the most common energy storage that can be integrated into grid connected PV system [2]. Solar PV energy systems are used to convert the trapped solar light into electricity [3]. The various power sources that are available may be invarious forms such as the utility grid, renewable power sources such as solar panel and DC energy storage units such as batteries [4]. Multiple energy sources are integrated in the microgrid to have for a reliable energy supply [5].

Batteries are everywhere, from power storage device in solar photovoltaic. Among them, lithiumion (Li-ion) batteries have become the most promising technology for energy storage due to their high energy density and high efficiency [6]. The energy management strategy should be determined among the renewables, energy storage and grid [7]. Batteries are used as power storage device in solar photovoltaic (PV) systems. They supply power when there is no solar power generation in the absence of sunlight [8]. The size of energy storage can be done using two types of batteries, namely Lead-acid Lithium-ion batteries and batteries. but it needs to be considered because there is a big difference between the minimum cost between a lead-acid battery and a Li-ion battery [9]. Battery has the advantages of high energy density, but with low power density, short cycle life, slow charging and discharging speed, and many other shortcomings [10, 11].

Control of these hybrid batteries within the same system is more challenging compared to conventional battery management systems which mainly deal with the homogeneous battery system [12]. 
State of Charge is an important parameter of the Battery Management System. It is an indication of the remaining battery capacity. It is very important to have an accurate estimate of the State of Charge, to avoid over charging and over discharging of Lithium ion batteries [13]. Battery management systems (BMS) to improve range prediction accuracy [14]. Lithium-ion cells also have a consistent maximum charge and discharge rate capability over the complete 0-100\% SOC range [15]. Existing charging techniques for lithium-ion batteries use a largely open-loop approach where the charge profile is pre-decided based on a priori knowledge of cell parameters [16]. The "constant-current and constant-voltage" charging mode is a widely used charging profile, in which a battery is charged with a constant current until a voltage limit is reached and then a constant-amplitude voltage is applied until the current reduces to a certain value, to charge the battery as fully as possible [17].

Charging the battery causes temperature rising [18]. A battery charger have to more intelligent and conscious of battery health and bring a positive impact on user satisfaction [19]. Battery charger have to meet the range of requirements, particularly in current ripples in battery float charge mode [20]. There are many factors that affect SOC, such as battery voltage, temperature, current, battery history, battery chemistry and so on. Ambient temperature is a significant factor that influences the accuracy of SOC estimation [21]. The SOC estimation can be improved by accurately calculating OCV using the proposed internalimpedance extraction from the battery [22]. Charging systems of battery electric current from the PV source with pulse charging technique is done to distribute high electric current to the battery without causing damage [23]. Charging time can be done using different sources, the duration of battery charging varies greatly depending on the AC source [24]. The batteries for photovoltaic systems need accurate, intuitive, and comprehensive electrical battery model which can sense the battery response under dynamic conditions [25].

This study discussed ways to improve the management system on battery charging and discharging. Automatic settings for selecting energy sources are also considered. A control system that has been built to overcome the problem of battery charging to avoid overcharging. The system designed is equipped with current and voltage sensors that can monitor current battery drainage. This system is equipped with protection against reverse electrical currents which can cause damage to the battery and the panel.

\section{RESEARCH METHOD}

Research method by designing hardware and software. The design of hardware and software will be explained in this section. The battery charging block diagram is shown in Figure 1.

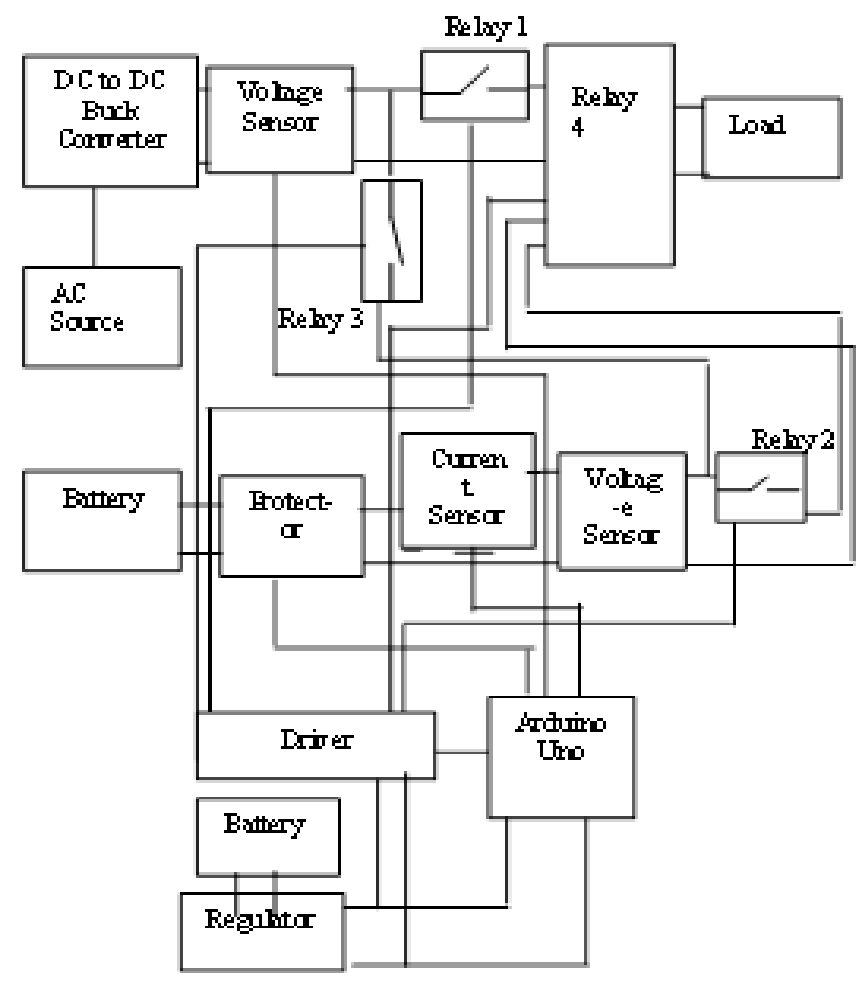

Figure 1. Block diagram of the battery charging for hybrid energy 


\subsection{System Design-Hardware}

Control system for battery charging are designed based on the block diagram that is shown in Figure 1. Protector in this design consist of a fuse and diodes. The protection circuit is used to protect the system from overload condition. Beside that when the battery voltage is greater than the solar module it is likely that the battery will send its voltage back to the solar module. This is where the blocking diode functions to protect the battery.

\subsection{System Design-Software}

Software that has been created using the Arduino IDE 1.6.4 softwear. Designing software based on flowchat which has been designed based on Arduino Mega 2560. To be able to upload software, a connection must be made to the Arduino port. The following is an explanation of the flowchart in Figure 2.

1) The control system always prioritizes the DC source rather than the battery when the DC source reaches the voltage that has been set and when the DC source is below that which has been set then selects the battery and displays it on the LCD screen.

2) The control system selects all switches off to load if all voltage sources are below $80 \%$

3) The control system charges when the battery capacity is below $80 \%$ and will stop charging when the battery capacity is $100 \%$ and displays this status on the LCD screen.

4) The control system disconnects if there is an overload and displays this status on the LCD screen.

5) The control system calculates the power load to the load and displays this status on the LCD screen.

6) The control system calculates and estimates the remaining battery time and displays this status on the LCD screen.

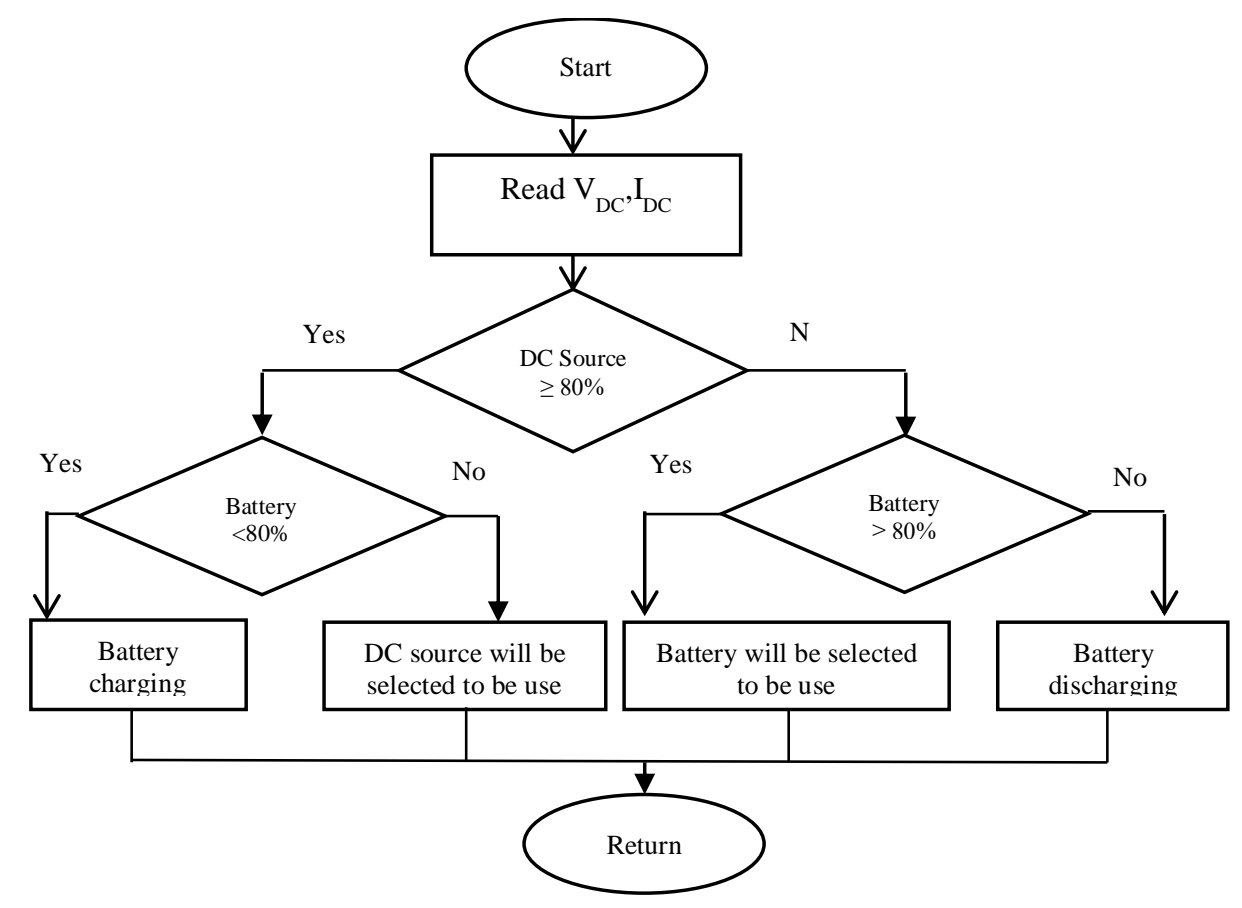

Figure 2. The Flow chart for the battery charging control program

\section{RESULTS AND ANALYSIS}

In this section, there are 3 parts of the design result, hardware, software, and test result.

\subsection{Hardware}

The hardware that has been designed is based on the block diagram in Figure 1. The battery charging control hardware consists of Arduino Mega 2560 as a microcontroller, regulator circuit, electric current sensor, voltage sensor, protection circuit, relay, and DC to DC Buck Converter.

DC to DC Buck Converter as a device to increase (Boost) or reduce (Buck) DC voltage. Buck DC to DC converter is for troubleshooting unstable voltages. The voltage sensor uses a module that can read voltage values ranging from 0 to up to 25 volts and requires a supply of $5 \mathrm{DC}$ volt. The current sensor that 
has been used in this system is INA 219. The INA219 sensor is a bi-directional system sensor using a shunt resistor. Relay driver is an electronic component that functions as an auxil-iary switch to move the load. Relay drivers are used to drive switches for electric current control. Relay drivers used amounted to 4 of them to set the source of the solar panel, regulate the battery source, regulate battery charging and the selection of voltage sources. The regulator uses IC 7805. Regulators are used to regulate the source voltage of a Li-Ion battery that has a voltage of 9 volts dc to a working voltage of 5 volts dc. The regulator circuit is used to provide power supply to the relay driver circuit. The realization of hardware development is shown in Figure 3 .

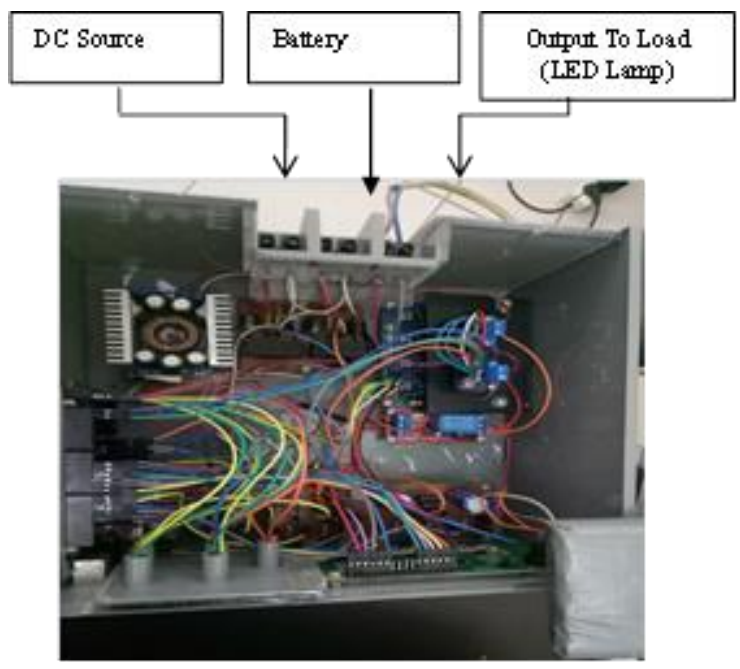

Figure 3. Picture of hardware from developing result a battery charging control system

\subsection{Selection of Voltage Sources Test}

Tests are carried out with the battery is set at 12.60 volt and the DC source is varied. The results are shown in Table 1. In Table 1 shows the control system always prioritizes DC sources or switch A when more than $12 \mathrm{~V}$ and the selector will selects the source from the battery (switch B) when the DC source is less than $12 \mathrm{~V}$.

Table 1. Selection of Voltage Sources Test

\begin{tabular}{ccccc}
\hline Step & $\begin{array}{c}\text { DC } \\
\text { Source } \\
(\text { Switch A) }\end{array}$ & $\begin{array}{c}\text { Battery } \\
\text { Voltages } \\
(\text { Switch B) }\end{array}$ & $\begin{array}{c}\text { Switch } \\
\text { Position } \\
\text { On relay } 4 \\
\text { (Switch A/B })\end{array}$ & $\begin{array}{c}\text { Output } \\
\text { Voltages }\end{array}$ \\
\hline 1 & 15,00 volt & 12,60 volt & A & 14,75 volt \\
2 & 14,35 volt & 12,60 volt & A & 14,20 volt \\
3 & 13,47 volt & 12,60 volt & A & 13,25 volt \\
4 & 12,76 volt & 12,60 volt & A & 12,48 volt \\
5 & 12,58 volt & 12,60 volt & A & 12,35 volt \\
6 & 12,40 volt & 12,60 volt & A & 12,10 volt \\
7 & 12,00 volt & 12,60 volt & A & 12,60 volt \\
8 & 11,92 volt & 12,60 volt & B & 12,60 volt \\
9 & 11,50 volt & 12,60 volt & B & 12,60 volt \\
10 & 11,00 volt & 12,60 volt & B & 12,60 volt \\
\hline
\end{tabular}

\subsection{Minimum Battery Capacity Test}

Testing aims to get system performance. Minimum battery capacity the allowable for supply of loads is $80 \%$. The test results show the system can work automatically disconnecting the battery to the load when the capacity is below $80 \%$. In Figure 4 shows relationship between percent of battery capacity and battery voltage. and for more detailed data can be seen in Table 2. In Table 2 the position of the switch NC or normally close means that the battery is connected to the load. While on the position switch NO or normally open means that the battery is not connected to the load. 


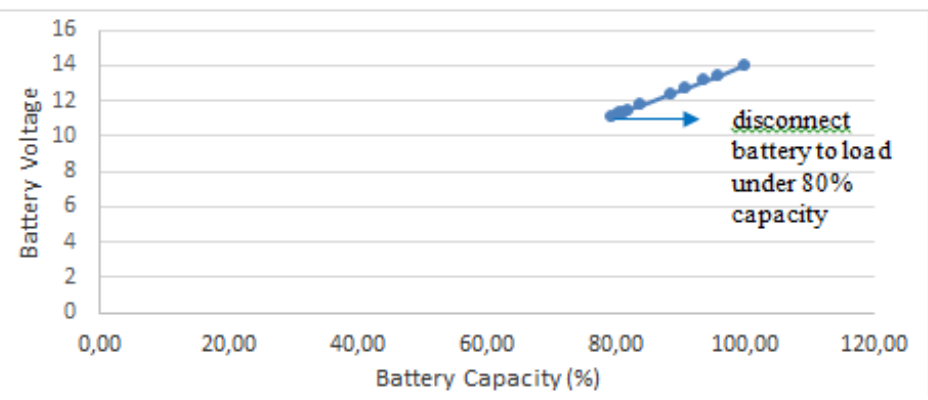

Figure 4. Relationship between percent of battery capacity and battery voltage

Relay 2 is the battery connecting switch to the load. When the battery capacity is below $80 \%$, relay 2 is off. When relay 2 is off, the battery is charging. The voltage requirement to the load is supplied by DC source. Data from battery capacity testing results are shown in Table 2. In Table 2 shows the results that when the battery voltage is smaller than 11.1 volts or the battery condition is under $80 \%$, relay 2 will cut the electric current to the load. In row 11 the battery voltage is less than 11.1 volts so relay 2 normally opens (NO). In Table 2 shows the results that when the battery voltage is smaller than 11.1 volts or the battery condition is under $80 \%$, relay 2 will cut the electric current to the load. In row 11 the battery voltage is less than 11.1 volts so relay 2 normally opens (NO).

Table 2. Minimum Battery Capacity Test

\begin{tabular}{cccc}
\hline No & $\begin{array}{c}\text { Battery } \\
\text { Voltage }\end{array}$ & \% Battery Capacity & Position of Relay 2 \\
\hline 1 & $14,00 \mathrm{~V}$ & $100.00 \%$ & $\mathrm{NC}$ \\
2 & $13,40 \mathrm{~V}$ & $95.71 \%$ & $\mathrm{NC}$ \\
3 & $13,13 \mathrm{~V}$ & $93.79 \%$ & $\mathrm{NC}$ \\
4 & $12,69 \mathrm{~V}$ & $90.64 \%$ & $\mathrm{NC}$ \\
5 & $12,40 \mathrm{~V}$ & $88.57 \%$ & $\mathrm{NC}$ \\
6 & $11,75 \mathrm{~V}$ & $83.93 \%$ & $\mathrm{NC}$ \\
7 & $11,45 \mathrm{~V}$ & $81.79 \%$ & $\mathrm{NC}$ \\
8 & $11,36 \mathrm{~V}$ & $81.14 \%$ & $\mathrm{NC}$ \\
9 & $11,30 \mathrm{~V}$ & $80.71 \%$ & $\mathrm{NC}$ \\
10 & $11,25 \mathrm{~V}$ & $80.36 \%$ & $\mathrm{NC}$ \\
11 & $11.1 \mathrm{~V}$ & $79.29 \%$ & $\mathrm{NO}$ \\
12 & $11 \mathrm{~V}$ & $78.57 \%$ & $\mathrm{NO}$ \\
\hline
\end{tabular}

\subsection{Charging and Discharging Battery Test}

Charging and discharging battery test are carried out to determine the work of the system designed. In Figure 5 shows the stage of charging the battery. The battery is charged based on DC source capacity. If the DC source is more than 0.9 amperes, it can charge the battery. Relay 3 is a switch connecting the DC source to the battery. Test results are shown in Table 3. In Table 3 shows that when DC source is 0.2 volts, 0.10 volts and 0.12 volts it cannot charge the battery. In order for the DC source to recharge it must be more than 0.9 volts.

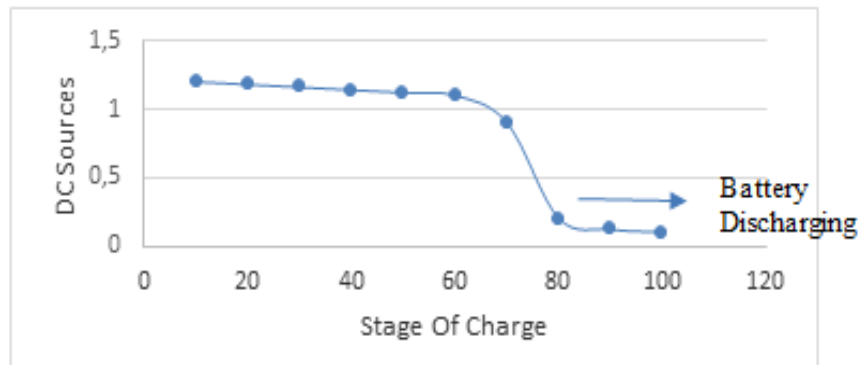

Figure 5. Relationship between DCsource and stage of charge 
Table 3. Charging and Discharging Battery Test

\begin{tabular}{cccc}
\hline No & $\begin{array}{c}\text { DC Source } \\
\text { (relay 2 ) }\end{array}$ & $\begin{array}{c}\text { Position of } \\
\text { Relay 3 }\end{array}$ & LCD Screen \\
\hline 1 & $1,2 \mathrm{~A}$ & $\mathrm{NC}$ & Battery Charging \\
2 & $1,18 \mathrm{~A}$ & $\mathrm{NC}$ & Battery Charging \\
3 & $1,16 \mathrm{~A}$ & $\mathrm{NC}$ & Battery Charging \\
4 & $1,14 \mathrm{~A}$ & $\mathrm{NC}$ & Battery Charging \\
5 & $1,12 \mathrm{~A}$ & $\mathrm{NC}$ & Battery Charging \\
6 & $1,10 \mathrm{~A}$ & $\mathrm{NC}$ & Battery Charging \\
7 & $0,90 \mathrm{~A}$ & $\mathrm{NC}$ & Battery Charging \\
8 & $0,2 \mathrm{~A}$ & NO & Battery Discharging \\
9 & $0,12 \mathrm{~A}$ & NO & Battery Discharging \\
10 & $0,10 \mathrm{~A}$ & NO & Battery Discharging \\
\hline
\end{tabular}

\subsection{Protection of Overload}

In this research an over current protection system performance test was also carried out. The purpose of this protection system is to protect the panel and load due to over current from the battery and DC source. Testing on short circuit safety uses detection from current sensor 1 . When the current sensor reads the current value of more than 5 amperes, the system will disconnect the current from the DC source and the battery source. The test results are shown in Table 4 .

Table 4. Protection of Overload

\begin{tabular}{|c|c|c|c|c|}
\hline No & $\begin{array}{l}\text { Current } \\
\text { Sensor } 1\end{array}$ & $\begin{array}{c}\text { Position } \\
\text { Of Relay } 1\end{array}$ & $\begin{array}{c}\text { Position } \\
\text { Of Relay } 2\end{array}$ & $\begin{array}{c}\text { LCD Screen } \\
\text { Status }\end{array}$ \\
\hline 1 & $1,1 \mathrm{~A}$ & $\mathrm{NC}$ & NO & $\begin{array}{l}\text { Select DC } \\
\text { Source }\end{array}$ \\
\hline 2 & $1,3 \mathrm{~A}$ & $\mathrm{NC}$ & NO & $\begin{array}{c}\text { Select DC } \\
\text { Source }\end{array}$ \\
\hline 3 & $2,8 \mathrm{~A}$ & $\mathrm{NO}$ & $\mathrm{NC}$ & Select Battery \\
\hline 4 & $3,2 \mathrm{~A}$ & $\mathrm{NO}$ & $\mathrm{NC}$ & Select Battery \\
\hline 5 & $5,1 \mathrm{~A}$ & $\mathrm{NO}$ & $\mathrm{NO}$ & Overload \\
\hline
\end{tabular}

\subsection{Calculation of Electric Power}

Electric power in Table 5 is obtained by multiplying the electric current and voltage. Based on the calculation results, the average power flowing to the load can be known. The maximum power that can be flowed is 50 Watt DC. Tests are carried out with LED light loads.For more detail the average battery power and DC source are shown in Table 5.

Table 5. Calculation of Electric Power

\begin{tabular}{|c|c|c|c|c|}
\hline \multirow{2}{*}{ No } & \multicolumn{2}{|c|}{$\begin{array}{c}\text { Source } \\
\text { Vottages } \\
\text { (Volt) }\end{array}$} & \multirow{2}{*}{$\begin{array}{c}\text { Electric } \\
\text { Current } \\
\text { (Ampere) }\end{array}$} & \multirow{2}{*}{$\begin{array}{c}\text { LCD } \\
\text { Screen } \\
\text { Electric } \\
\text { Power (Watt) }\end{array}$} \\
\hline & $\begin{array}{c}\text { DC } \\
\text { Source }\end{array}$ & Battery & & \\
\hline 1 & $15,00 \mathrm{~V}$ & - & 1,10 & 16,5 \\
\hline 2 & $14,49 \mathrm{~V}$ & - & 0,52 & 7,5 \\
\hline 3 & $13,80 \mathrm{~V}$ & - & 1,16 & 16 \\
\hline 4 & $13,09 \mathrm{~V}$ & - & 0,91 & 11,9 \\
\hline 5 & $12,09 \mathrm{~V}$ & - & 0,43 & 5,2 \\
\hline 6 & - & $12,80 \mathrm{~V}$ & 1,24 & 15,8 \\
\hline 7 & - & $12,72 \mathrm{~V}$ & 1,81 & 23 \\
\hline 8 & - & $12,67 \mathrm{~V}$ & 1,53 & 19,3 \\
\hline 9 & - & $12,15 \mathrm{~V}$ & 0,9 & 10.9 \\
\hline 10 & - & $11,70 \mathrm{~V}$ & 0,3 & 3.51 \\
\hline
\end{tabular}

\subsection{Duration Time of the Battery}

The remaining time is the duration of time the battery will run out of energy. In this study using battery with $14 \mathrm{~V} 5 \mathrm{Ah}$. If the average electric current used is $5 \mathrm{~A}$, the battery usage time is 1 hour. In Figure 6 shows that the more electric current the battery uses, the battery energy will also run out faster. 


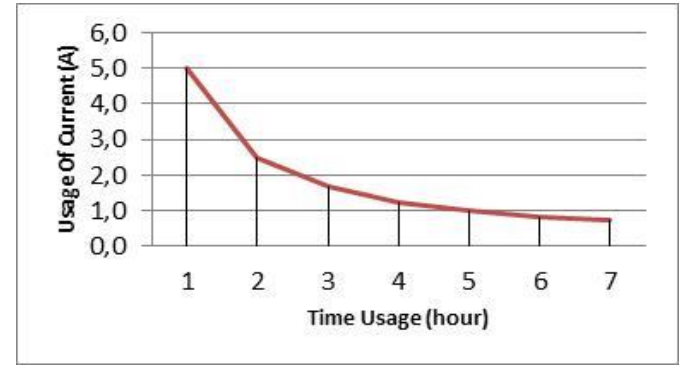

Figure 6. Relationship between usage current and time duration battery

In Table 6 is the estimation of the duration of time based on the use of electric current batteries usage. A battery with $5 \mathrm{Ah}$ means that the average current used in 1 hour is 5 amperes. If use an average electric current of 0.7 amperes, the duration of the battery reaches 7 hours. For more details are presented in Table 6.

Table 6. Time Remaining on the Battery

\begin{tabular}{ccccc}
\hline No & $\begin{array}{c}\text { \% Battery } \\
\text { Capacity }\end{array}$ & $\begin{array}{c}\text { Battery } \\
\text { Ah Value }\end{array}$ & $\begin{array}{c}\text { Usage of } \\
\text { Current } \\
\text { (Ampere) }\end{array}$ & $\begin{array}{c}\text { Duration } \\
\text { Time } \\
\text { (hour) }\end{array}$ \\
\hline 1 & 100 & 5 & 5.0 & 1 \\
2 & 100 & 5 & 2.5 & 2 \\
3 & 100 & 5 & 1.7 & 3 \\
4 & 100 & 5 & 1.3 & 4 \\
5 & 100 & 5 & 1.0 & 5 \\
6 & 100 & 5 & 0.8 & 6 \\
7 & 100 & 5 & 0.7 & 7 \\
\hline
\end{tabular}

\section{CONCLUSION}

Based on the results of testing and analysis that has been carried out the charge controller battery can work well even with low cost materials. The battery charge controller can choose the right energy form DC source when the voltage more than $12 \mathrm{~V}$ and the battery voltage less than 12.60 volts. And also when the DC source is less than $12 \mathrm{~V}$ and the battery voltage is 12.60 volts, the system selects the battery source. The control system can also work well when the battery voltage $<11.1$ volts than relay 2 will cut the electric current to the load. The DC source cannot charge the battery if the voltage is less than $80 \%$. In order for a DC source to charge the battery it needs more than $80 \%$ voltage. This BCR protection system also works well. When the sensor reads a current value of more than 5 amperes, the system will disconnect the current from the DC source and battery source.

\section{REFERENCES}

[1] Răzvan Florin Pantelimon, Maricel Adam, MihaiAndruşcă, CătălinPancu, "Aspects Regarding Solar Battery Charge Controllers" The 8th International Symposium On Advanced Topics In Electrical Engineering May, 2013.

[2] Aimie Nazmin Azmi, Norhafiz Salim, Aziah Khamis, "Analysis of an energy storage sizing for grid-connected photovoltaic system," Indonesian Journal of Electrical Engineering and Computer Science (IJEECS), vol. 16, no. 1, pp. 17 24, October 2019

[3] Jawahar M, Jayasankar V, Karthik Kumar K, Edward Rajan S,'Efficiency enhancement of solar PV powered micro-integrated high frequency isolated vehicle battery charging converter," International Journal of Power Electronics and Drive System (IJPEDS), vol. 10, no. 2, June 2019

[4] D Sattianadan, K Saravanan, S. Murugan, N. Hari, P. Venkadesh, "Implementation of quasi-z source inverter for grid connected PV based charging station of electric vehicle," International Journal of Power Electronics and Drive System (IJPEDS), vol. 10, no. 1, March 2019

[5] M. Reyasudin Basir Khan, Jagadeesh Pasupuleti, Jabbar Al-Fattah, Mehrdad Tahmasebi, "Energy management system for PV-Battery microgrid based on model predictive control,"Indonesian Journal of Electrical Engineering and Computer Science (IJEECS), vol. 15, no. 1, pp. 20 25, July 2019

[6] Raffaele Romagnoli, Luis D. Couto, Marco M. Nicotra, Michel Kinnaert, EmanueleGarone, "ComputationallyEfficient Constrained Control of the State-of-Charge of a Li-ion Battery Cell," IEEE 56th Annual Conference on Decision and Control (CDC), December 2017

Battery charging and discharging control of a hybrid energy system using... (Triyanto Pangaribowo) 
[7] Taoyong Li, Jing Zhang, Yuanxing Zhang, Linru Jiang, Bin Li, Dongxiang Yan, Chengbin Ma,"An Optimal Design and Analysis of A Hybrid Power Charging Station for Electric Vehicles Considering Uncertainties," IECON 2018 44th Annual Conference of the IEEE Industrial Electronics Society, 2018

[8] Quan Ouyang; Jian Chen; JianZheng; Huazhen Fang," Optimal Multi-Objective Charging for Lithium-Ion Battery Packs: A Hierarchical Control Approach," IEEE Transactions On Industrial Informatics, pp: 1-1, 2018

[9] Joydip Jana, HiranmaySamanta, Konika Das Bhattacharya, HiranmaySaha, "A Four Stage Battery Charge Controller Working on a Novel Maximum Power Point Tracking Based Algorithm for Solar PV System", 21st Century Energy Needs - Materials, Systems and Applications (ICTFCEN), pp. 1-4, 2016

[10] Victor Herrera, AitorMilo, Haizea Gaztañaga, Ion Etxeberria Otadui, Igor Villarreal, Haritza Camblong," Adaptive energy management strategy and optimal sizing applied on a battery-supercapacitor based tramway,"Applied Energy, vol. 169, pp. 831-845, May 2016

[11] Ting-Long Pan,Hong-ShuWan,Zhi-Cheng Ji,"'Stand-alone wind power system with battery/super capacitor hybrid energy storage," International Journal of Sustainable Engineering, 2014

[12] Nilanjan Mukherjee, Dipankar De," A New State-of-Charge Control Derivation Method for Hybrid Battery Type Integration," IEEE Transactions on Energy Conversion, Vol. 32, No. 3, 2017

[13] Mahesh S. Chitnis, Sachin P. Pandit, Mr. M. N. Shaikh, "Electric Vehicle Li-Ion Battery State of Charge Estimation using, "Artificial Neural Network. Proceedings of the International Conference on Inventive Research in Computing Applications, IEEE, 2018

[14] Shady Gadoue, Kuan-Wen Chen, Paul Mitcheson, Vladimir Yufit, Nigel Brandon," Electrochemical Impedance Spectroscopy State of Charge Measurement for Batteries using Power Converter Modulation," The 9th International Renewable Energy Congress,IEEE, 2018

[15] Mahesh Padmanabh, Manoj Madhukar Desai,"Performance and Dynamic Charge Acceptance estimation of different Lithium-Ion batteries for Electric and Hybrid Electric Vehicles," 2017 IEEE Transportation Electrification Conference (ITEC-India), IEEE, 2017

[16] Lalit Patnaik, A. V. J. S. Praneeth, Sheldon S. Williamson,"A Closed-loop Constant-temperature Constant-voltage Charging Technique to Reduce Charge Time of Lithium-ion Batteries," IEEE Transactions On Industrial Electronics, vol. 66, Issue: 2, 2019

[17] Jung-Hoon Ahn, Byoung Kuk Lee, "High Efficiency Adaptive-Current Charging Strategy for Electric-Vehicles Considering Variation of Internal Resistance of Lithium-ion Battery," IEEE Transactions on Power Electronics, vol. 34, Issue. 4, 2019

[18] Chien-Wu Lan, Shih-Sung Lin, Sih-Yan Syue, Hao-Yen Hsu, Tien-Cheng Huang, Kuang-Hsiung Tan,"Development of an Intelligent Lithium-Ion Battery-Charging Management System for Electric Vehicle,"Proceedings of the 2017 IEEE International Conference on Applied System Innovation,2017

[19] Quan Ouyang; Jian Chen; JianZheng; Huazhen Fang," Optimal Multi-Objective Charging for Lithium-Ion Battery Packs: A Hierarchical Control Approach" IEEE Transactions On Industrial Informatics, pp: 1-1, 2018

[20] Aleksandr D.Kupchinov, Nickolay N. Smotrov, Yury P.Gusev,"The Compatibility Verification of Batteries and Battery Chargers to Ripples in Battery Float Charge Mode," IEEE Conference of Russian Young Researchers in Electrical and Electronic Engineering,2018

[21] Shuxiang Song, Zhenhan Wei1,Haiying Xia, Mingcan Cen,Chaobo Cai, "State-of-charge (SOC) estimation using T-S Fuzzy Neural Network for Lithium Iron Phosphate Battery" 26th International Conference on Systems Engineering (ICSEng), IEEE, 2018

[22] Jun-ichi Nagata, Kenichi Kawasaki and Hiroyuki Nakamoto,"A Battery Management System Adapted for an Energy Harvester with a Low-Power State of Charge Monitoring Method and a 24 Microwatt Intermittently Enabled Coulomb Counter,"IEEE Applied Power Electronics Conference and Exposition (APEC), 2018

[23] Budi Amri, Soedibyo, "Design of Batteries Charging by Charge Management Concepts on Photovoltaic Standalone System," IEEE, International Seminar on Application for Technology of Information and Communication, 2016

[24] Gilfred Allen Madrigal, Kristin Gail Cuevas, Vivien Hora, Kristine Mae Jimenez, John Niño Manato, Mary Joy Porlaje, BenedictoFortaleza,"Fuzzy logic-based maximum power point tracking solar battery charge controller with backup stand-by AC generator," Indonesian Journal of Electrical Engineering and Computer Science (IJEECS), vol. 16, No. 1, pp. 136 146,2019

[25] B V Rajanna, MalliguntaKiran Kumar,"Dynamic model development for lead acid storage battery,"Indonesian Journal of Electrical Engineering and Computer Science (IJEECS),vol.15, no. 2, pp. 609 619,2019 